\title{
CCTV Surveillance ANd the Civic Conversation: A Study in Public SocIOLOGY
}

\author{
DAN LETT \\ SEAN P. HIER \\ KEVIN WALBY
}

\begin{abstract}
Public sociology is being debated across the social sciences. This article examines how sociologists can enter concretely into a civic conversation through the research process. We present partial findings from a Canada-wide investigation into how city street video surveillance systems are implemented in various communities. Our aim is to examine some of the challenges of doing public sociology by examining sociological knowledge production and communication with diverse publics. Data gleaned from focused group interviews in the City of Kelowna, British Columbia are presented to explore the challenges of facilitating a civic conversation about public policy on city street video surveillance.
\end{abstract}

Keywords: public sociology; public-area video surveillance; Burawoy; public opinion

Résumé : La notion captivante de "sociologie publique » a récemment animé des débats dans le monde des sciences sociales. Bien que ces débats aient permis de soulever des questions pertinentes relativement au statut de la production du savoir sociologique, on n'a pas apporté suffisamment de réflexion sur la manière dont les sociologues entrent réellement dans une conversation civique à travers le processus de recherche. Pour combler cette lacune dans la documentation en sociologie publique, nous présentons des résultats partiels obtenus à partir d'une investigation à l'échelle nationale sur les stratégies d'implantation des systèmes de vidéosurveillance dans les lieux publics que sont les rues dans diverses communautés, afin de réfléchir à quelques-unes des implications que cela soulève lorsqu'on pratique véritablement de la sociologie publique. Les données recueillies à partir d'interviews de groupes ciblés dans la ville de Kelowna, Colombie-Britannique, seront présentées dans le but d'explorer les défis imposés par la mise en place d'une conversation civique relativement aux politiques publiques de la vidéosurveillance des rues.

Mots clés: sociologie publique; vidéosurveillance dans les lieux publics; Burawoy; opinion publique 


\section{INTRODUCTION}

Michael Burawoy's presidential address to the American Sociological Association in 2004 stimulated international dialogue and debate about public sociology (see Burawoy 2005a). Burawoy argued that the growing appeal of sociology concerning the issues facing modern societies means that sociologists must develop new ways to meaningfully engage with multiple publics. He also argued that critical sociologists are well positioned to provide the moral and political defense of civil society that public sociology requires (see Burawoy 2005c). Although Burawoy encouraged reflection on the direction and obligations of the discipline, insufficient attention has been devoted to thinking about how sociologists enter concretely into a civic conversation on public policy matters with "thick" and "thin" publics (but see Burawoy 2004).

Drawing from our research on city street video surveillance monitoring programs in Canada, we reflect on some of the ways that our work intersects with the goals of public sociology. Since 2005, we have been investigating the implementation of video surveillance technologies in cities across Canada (see Hier 2010). The investigation examines the decision-making and planning processes involved in establishing monitoring systems (see Hier et al. 2007; Hier et al. 2006). ${ }^{1}$ The overall project is not explicitly conceptualized as a study in public sociology, yet our research adheres to Burawoy's formulation in at least two overlapping ways.

To understand how communities plan for and react to city street video surveillance systems, first, we identify and engage with a diverse range of publics involved in the process of establishing and promoting monitoring systems. Most of our interactions take place in the context of interviews and control room observations with system representatives and project managers but we also engage with civil libertarians, community groups, and members of various publics that circulate in urban environments. These groups can be thought of as "thick" publics (see below) who have established protocols for knowledge production and communication. We have also interviewed groups that are "thinner" publics; they are visible but share no knowledge production and communication protocols or orientations to social problems. In this article, we assess how hybrid thick-thin publics respond to the communications and research initiatives of sociologists.

1. We have conducted more than 400 interviews to understand how city street video surveillance monitoring systems are promoted and designed. There are currently at least 25 Canadian cities running video surveillance monitoring programs to survey city streets. 
Our study is motivated, second, by a shortcoming in public dialogue about video surveillance. It is rare to find video surveillance promotional efforts informed by interactive public dialogue, and we seek to address these limitations through publishing and presenting empirical findings, as well as by facilitated communication among diverse publics. Our research reveals that a small (and selective) body of social-scientific literature influences video surveillance policy formation. We introduce a broader range of sociological findings into the ongoing process of establishing and maintaining video surveillance systems across the country. ${ }^{2}$

In the course of our research, we conducted a study on public perceptions of and experiences with video surveillance in Kelowna, British Columbia. From 2001-2008, the Royal Canadian Mounted Police (RCMP) used a video surveillance system to survey the Queensway bus loop district and the area surrounding the corner of Leon Avenue and Abbott Street in downtown Kelowna. ${ }^{3}$ This monitoring program was promoted by RCMP, business, and city representatives to respond to perceptions of rampant drug trafficking, violence, and aggressive panhandling in the downtown area. We held focused group interviews with residents of shelters and seniors' homes in downtown Kelowna.

These publics were selected because seniors and "street" populations are commonly invoked in official promotional communications and informal claims about the need for video surveillance in Kelowna, yet neither group has been consulted about the monitoring program.

The lack of consultation is significant because one of the main guidelines for the use of video surveillance by public bodies and law enforcement agencies published by the Office of the Privacy Commissioner of Canada (OPC) - the privacy protection agency with jurisdiction over the RCMP in Kelowna - is extensive public consultation. ${ }^{4}$ The OPC

2. In some countries - most notably the United Kingdom - the establishment of public video surveillance systems entails standardized policy-making and funding programs. Canada has no federal video surveillance policy, and provincial-level coordination is nascent at best. Individual municipalities and other communities often instigate and develop their own surveillance practices with minimal coordination, research resources, or awareness of other programs in Canada.

3. The Leon and Abbot cameras overlook both of the downtown support shelters featured in this study, as well as an adjacent park used by the "street" population, tourists, and other downtown residents. The Queensway bus-loop, the transport hub of the city, is used by a broad spectrum of residents. Vandalism and vagrancy at Queensway are issues that the cameras were intended to address. Kelowna's CCTV program remains operational, but is being reconfigured in 2010-2011 with the aid of funding provided by $\mathrm{BC}$ provincial authorities.

4. The OPC, along with several provincial privacy commissioners' Offices, offers guidelines for establishing video surveillance programs conducted by "public bodies." The guidelines identify a number of "principles" informing the use of overt, general video surveillance. These principles include provisions for determining the necessity for video surveillance as a last resort and the importance of conducting privacy impact 
(2006) stipulates that a specific geographic area may have several distinct communities; one community should not be presumed to speak for others.

This lack of consultation in Kelowna and elsewhere matters in the context of Burawoy's concerns about civil society. Video surveillance policymaking is one area where opportunities to engage in civic conversation are unequally distributed among different publics. Critical sociological and criminological texts identify public video surveillance as a concern - or at least a matter to be aware of and understand - for many types of public (Huey 2010; Hier 2010; Bennett and Bayley 2005). As the growth of public video surveillance in Canada suggests, "problems" defined by sociologists are unreliable predictors of the issues that mobilize various social groups. Empirical studies that engage hitherto absent publics in conversations about issues that seem to concern them - as our study seeks to do - are a key component in efforts to promote inclusive debates on policy. They are, therefore, consistent with the goal of public sociology.

The article is organized in four parts. We begin by explaining some of the goals of public sociology. We then report on our method and explain how our research intersects with the goals of public sociology. In the third section, we present results from our interviews, emphasizing numerous practical challenges encountered in facilitating a civic conversation with these publics. We conclude by discussing the implications of our findings for the public sociology venture.

\section{Public Sociology}

Burawoy (2005a) identifies four types of sociology that graft on to two knowledge orientations. Professional and policy sociology constitute instrumental knowledge. Whereas professional sociology concerns the internal organization, conceptual frameworks, and methodological techniques of sociology, policy sociology is defined as "sociology in the service of a goal defined by a client" (Burawoy 2005a:266). Both types of instrumental sociological knowledge are oriented toward solving specific problems for academic audiences and/or policy communities.

By contrast, Burawoy (2005a) conceptualizes sociological knowledge oriented towards discerning problems and objectives as reflexive knowledge. Reflexive knowledge is constituted by critical and public

assessments; public consultations and the legality of monitoring practices; collection of personal information, the formation of surveillance policies, and design and implementation concerns; and matters pertaining to the access, use, disclosure, auditing, and disposal of records. 
sociology. Critical sociology examines the "foundations - both the explicit and the implicit, both normative and descriptive - of the research programs of professional sociology" (2005a:268). Critical sociology is concerned with what Said (1994:85) describes as the task of "speaking truth to power." The critical sociologist is "neither a pacifier nor a consensus-builder" (1994:23), but someone who maintains a state of alertness about power dynamics in everyday life. Critical sociology identifies problems and formulates research agendas that promote solutions. For Burawoy, critical sociology must also defend and develop the communicative conditions necessary for sociology's problem-solving utility to be realized - a task understood as the defence of civil society.

Public sociology can be conceptually located at the intersection of instrumental and reflexive knowledge. On the one hand, public sociology is similar to critical sociology; it is driven by a normative imperative to "do" sociology beyond the academy by "promoting dialogue about issues that affect the fate of society, placing the values to which we adhere under a microscope" (Burawoy 2004:104). On the other hand, Burawoy's (2005a) conceptualization of public sociology is compatible with instrumental forms of knowledge acquisition. In this sense, public sociology offers a form of reflexive instrumentalism. Public sociologists, says Burawoy, enter into dialogue with publics to explore practical and policy solutions to a range of social problems.

Burawoy argues that there are two approaches to "doing" public sociology that roughly correspond to two types of public. Publics who are "invisible in that they cannot be seen, thin in that they do not generate much internal interaction, passive in that they do not constitute a movement or organization" (Burawoy 2005:263) may be responsive to "traditional" public sociology. Traditional public sociology involves communication and knowledge production that is customary amongst academics, such as the publishing of books, articles, and opinion pieces in newspapers. Conversely, "visible, thick, active, local" (2005:264) publics are suitable for direct engagements understood as "organic" public sociology. Organic public sociology may include advocacy work, participatory action research (PAR), or institutional ethnography.

Burawoy's dual concept of publics is crucial to the question of how to "do" public sociology. Many responses to Burawoy's work address how these two types of publics can be defined and engaged (see Mesny 2009; Piven 2007; Acker 2005; Ryan 2005; Brady 2004). Although the public sociology literature has yet to develop consistent definitions of the two types of public, generally they may be understood in terms of three levels of integration: (1) internal and external recognition as a group by virtue of institutional association and/or life situation (visibility), 
(2) shared knowledge-production and communication protocols (coherence), and (3) productive orientation to commonly understood issues or problems (activity) (see Glenn 2007; Ericson 2005; Beck 2005; Calhoun 2005). We understand groups with strong integration at all three levels as "thick" publics, and those with weaker integration as "thin" publics. Thick publics are contenders for organic public sociology, whereas thin publics are conventionally addressed via traditional public sociology.

Burawoy's encouragement of a reflexive instrumentalism - that is, a critically engaged sociology that has practical applications - is commendable. Burawoy is also correct to promote the incorporation of more integrated forms of engagement with the existing status quo of traditional public sociology. In our experience investigating the emergence of city street video surveillance in Canada, Burawoy's argument that sociology is not taken seriously at the level of public policymaking has resonance (2005c:419-21; see also Davis 2004; Johnson 2004; Wiles 2004; and see Haggerty 2004 and Matthews 2009 on similar trends in criminology). For example, on several occasions we have observed the strategies used by authorities to assess potential impacts of a monitoring program on their community's concerns (whether formally through privacy impact assessments or informally through selective consultations). With few exceptions, authorities are unaware of the many published sociological studies that would aid them in their decision making (e.g., Waples and Gill 2006; Gill and Spriggs 2005; Welsh and Farrington 2004; Gill 2003). ${ }^{5}$

Following Kalleberg (2005), we could attribute lack of awareness amongst authorities to inadequacies in sociologists' professional obligation to circulate research findings. We could also surmise that authorities are under no obligation to take sociological research on video surveillance into consideration. When sociological research is considered, authorities tend to selectively interpret, or simply refute, findings to legitimize preconceived policies under institutional pressures (Hier 2010). These tendencies are particularly problematic when authorities act as secondary disseminators, passing their interpretations of research to the publics to whom they are responsible, and who seldom have the time to conduct their own research into the policy decisions affecting their lives.

Most of the interviews we conducted in our broader investigation of video surveillance in Canada were with thick publics who usually feature in organic public sociology (Burawoy 2005a) owing to their in-

5. The general finding of these studies is that public-area video surveillance is most effective at reducing property-related crime in contained spaces (e.g., a parking garage). Evidence suggests that streetscape systems do not reduce violent crimes, yet this is a primary justification for streetscape systems. 
stitutional status (e.g., politicians, police), their stakeholder status (e.g., business owners), and their political interest (e.g., civil libertarians, activists). Frequently we make contact with thick publics who are actively embroiled in developing or (more rarely) contesting public video surveillance programs. Our efforts to engage and provide sociological materials that relate to their objectives receive mixed responses. Public camera surveillance promoters often employ rationales that complement their broader political beliefs and local aims - contradictory sociological research is easily dismissed as too general, secondary to local knowledge of specific downtown problems, or even intrusive. As Piven (2007) notes, thick publics are unlikely to be receptive to organic public sociology except on their own terms.

Sometimes our research project engages thick publics who are receptive to our input, and a relationship of "mutual education" (Burawoy 2005:263) develops. These publics fall into one of three categories: (1) those whose institutional logics are compatible with the type of knowledge produced by traditional sociological and criminological research (e.g. police), (2) those seeking to further legitimize their promotional/ oppositional efforts, and (3) publics with a self-identified need for more resources with which to make their decisions. To illustrate, we offer three examples from our research.

First, we recently established a relationship with city staff from a municipality who had been granted funding to develop a monitoring program. Their program was integrated into a strategy of crime prevention through environmental design. Our input was received with interest: we were in a position to explain research findings that address their objectives of reducing property crime in local parking facilities.

Second, we recently worked closely with a hybrid municipal/police organization providing public camera surveillance monitoring services for a major international sporting event. Program managers were under political pressure to address civil libertarian and privacy-related concerns raised by city council. We were invited to critically observe monitoring practices and directly contribute to the formation of a defensible and "regulation-exceeding" set of operational guidelines.

Finally, in several communities, upon making contact with members of city staff researching public camera surveillance, we have been asked to explain sociological research findings on video surveillance practices, including our own empirical observations of similar programs. Our input has helped cities revise their objectives and expectations; in some cases, cities halted their public camera surveillance plans.

The hybrid thick-thin publics we consulted for this study presented a new set of dynamics. Their group visibility and internal coherence may 
be strong in some respects, yet their activity and orientation (to the issue of city street video surveillance) shows limited integration. Burawoy's model is less clear on how hybrid publics may be engaged. While publics like the seniors and shelter clients of Kelowna lack the integration for organic public sociology, it is also unclear whether traditional public sociology registers across their platforms for knowledge-formation and communication. Certainly in the case of public video surveillance, conventional methods of disseminating sociological research have not resulted in extensive awareness or inclusive debate. Our interviews shed some light on the possibilities and difficulties of directly engaging hybrid publics, and ultimately, on the prospects for reflexive instrumentalism.

\section{The STudy}

Like other social problem constructions (see Best 2004), proponents of video surveillance commonly typify publics whose activities and interests in urban spaces will be either safeguarded or curtailed by video surveillance monitoring programs. Actual publics implied in such typifications are afforded limited access to debate, owing in large part to the shortcomings of official consultation processes. To address the lack of consultation, we incorporated focused interviews with groups of people who are identified in promotional and justificatory rhetoric into our research design. Our intention was to examine public perceptions of and experiences with video surveillance, to extend the conversation about video surveillance to publics affected by the cameras, and to assess the assumptions about publics that underpin justifications for such systems.

We conducted four sets of focused group interviews with downtown residents in the City of Kelowna. Traditional focus groups are primarily associated with market-driven research designed to gather feedback on products or services (i.e., consumer reactions); focused group interviews involve interactively questioning a group of participants in similar social locations to test theory-driven hypotheses (Grim et al. 2006). Focused group interviews simultaneously enable participants to interact in a shared setting, and enable interviewers to gather a large amount of data in a short period of time by guiding discussions towards specified topics (Morgan 1997:8-17).

We chose Kelowna because the promotion of the system featured typifications of downtown populations, and was characterized by a lack of public consultation. We used a purposive sampling strategy informed by promotional claims made by official stakeholders who designed the 
system. ${ }^{6}$ Like other public policy issues, city street video surveillance is invested with meaning through the manifold ways that social problems are constructed and negotiated by claims makers. The primary group identified as problematic in Kelowna is the so-called transient population. In crime control discourse amongst business people, RCMP representatives, and city officials, the transient population is composed of a diverse group of undesirable residents. Part of the perceived problem with transients stems from opportunities for casual seasonal work in $\mathrm{Ke}$ lowna's local orchards, as well as a regional tendency to attract seasonally rough-sleepers from cooler climates (e.g., Calgary). But the transient signifier also extends to local homeless people and drug users who dwell in and around the downtown core.

The second group identified in crime control discourse is seniors. Kelowna has a large retired population; inherently vulnerable seniors are identified as likely beneficiaries of city street cameras. ${ }^{7}$ In written and oral communications, program stakeholders explicitly refer to the transient problem and the desire to make seniors feel safer in justifying Kelowna's cameras.

The four interview groups (a total sample size of twenty-eight participants) were composed of ten temporary residents of the Gospel Mission, a Christian charity offering shelter and food to homeless and elderly men; five patrons of the Drop-In Centre, a support shelter offering food and services to homeless and needy men and women; and thirteen residents of two downtown seniors homes (interview groups consisted of five and eight participants). Morgan (1997:43) recommends four to eight interviewees as the ideal number of group participants. However, the nature of our research populations posed difficulties in planning interviews. For example, we visited the Gospel Mission the night prior to scheduled interviews and recruited six men as they were bedding down for the night. When we returned the next morning, the number of interested clients grew to ten (two participants slept through the interview). At one of the seniors' residences, an outbreak of illness reduced the group of seven to five. It was impossible to enlist female clients of the

6. Prior to focused group interviews, we conducted interviews with representatives of the City of Kelowna, the RCMP, the business community, and support services. The "transients" epithet is a dominant typification of problem populations in downtown Kelowna.

7. Census data shows that $18.4 \%$ of the resident population in Kelowna were of retirement age in 2000, compared with the Canadian mean of $13.2 \%$ (Statistics Canada 2001). In addition, the reputation of Kelowna as a "retirement community," and the high concentration of seniors' residences in and around the downtown area, perhaps explain why "seniors" especially are represented as being either at risk from certain behaviour in the downtown, or negatively affected by the fear of crime. 
support shelters: the Gospel Mission is a men-only establishment, and the female clients of the Drop-In Centre were unwilling to be recorded.

The interviews entailed a set of general questions about video surveillance and perceptions of public safety and other problems in downtown Kelowna. During interviews, we introduced evidence-based information about the monitoring system in Kelowna and about findings from international studies concerning the effectiveness of video surveillance cameras in reducing crime to see how it affected participants' reflections on cameras.

\section{CCTV, Public Safety and Downtown Problems in Kelowna}

Each interview featured a standardized set of questions about safety and social problems in downtown Kelowna. ${ }^{8}$ Knowing that groups such as homeless persons and seniors have diverse understandings of public issues (Huey 2010), we established a context of group-specific perceptions of personal safety to explore the "thickness" of each public. On the whole, shelter clients have fewer safety concerns; they consider downtown issues to be overplayed:

Jacob: I feel safe downtown. A lot of people are afraid to be downtown, you get a lot of people saying, "oh it's scary downtown." There's nothing to be scared of. People who look at people on the street are scared because they assume something. If you don't bother them, they're not going to bother you.

"Street-wise" knowledge is considered adequate defence against most downtown issues, but shelter clients have specific concerns about police.

R: Do you feel safe just hanging around in downtown Kelowna?

Bob: If I see the police, a big red light goes on.

Joe: I've been beaten up by police, by the RCMP. I got picked up for being drunk in public when I wasn't even drunk ... they broke my nose and they smashed me out, all over nothing.

8. Where excerpts are presented, participants' names have been changed. "R" denotes the researcher; individual participant's contributions are indicated by a single first name. We use the conventions of transcription notation outlined in Deacon et al. (1999). "( )" indicates indecipherable utterances; “...” indicates an omission within a turn of speaking; "(...)" indicates an omission that extends beyond one turn of dialogue; descriptions of nonverbal behaviour are in square brackets "[ ]"; a blank line left between blocks of quotation indicates quotes taken from different discussions, but related to the same issue. 
Shelter clients consider traffic a bigger danger than interpersonal threats.

$\mathrm{R}$ : What kind of thing would make you watch your back?

Anthony: The way people drive ... there's been a few brothers in Kelowna been hit by, very close by, the way people drive nowadays.

Peter: Then out of nowhere Welsh gets hit by a car. Hit and run, no-one ever gets charged. Now Welsh is a vegetable pretty much, poor guy, he's not the same. Brain-dead now. ${ }^{9}$

Shelter clients generally identify police harassment, disproportionate prosecution of offences committed by street people, and a lack of social services as more pressing problems than immediate safety fears.

Seniors' personal safety concerns are more pronounced but less specific, centring on what they perceive to be threatening types of people associated with declining social conditions.

R: What makes you feel unsafe?

Edith: Just the people that are around you. Gangs (...) and it's just, um, I think it's part of being old [laughs]. It's just a reaction to, as I say, gangs and sometimes the street is so full of people and I'm not used to that.

R: So what do you think of Kelowna's downtown area? Is it a nice place to be?

Chester : No. Used to be, not now.

Brenda: Too many transients downtown. You have to step over them on the sidewalk...you just don't feel safe downtown anymore.

However, seniors recount few personal experiences where their own safety was in danger, and tend to echo shelter clients' views that $\mathrm{Ke}$ lowna is not as bad as nonresidents perceive.

R: If you didn't live downtown, but you got all your information and impressions about downtown from friends, do you think you'd get the idea that downtown was worse than it actually is?

Jack: You'd drive with the windows up and the doors locked. You'd not stop.

9. The Gospel Mission and the Drop-In Centre are located one block away from the busy Highway 97. Two cheap restaurants and a convenience store with bathroom facilities are located on the other side of the highway. Some of the Gospel Mission participants report a fear of crossing the street to reach these services. "Welsh" is a former Gospel Mission resident who earned money "squeegeeing" cars until his accident. 
It is no surprise that matters of personal safety divide the two groups. Signs of potential violence and danger are relative to the social identity of the individual (see Dovey et al. 2001). With little variation, shelter clients and seniors have distinct concerns related to their life situations that partially constitute their identities as thick publics. One challenge the public sociologist faces in the field is how to reconcile the fact that various publics perceive issues such as safety very differently. An added complication is that publics may ostensibly agree on what constitute certain problems (e.g., open drug-use, violence), and even employ the same language to describe problems (e.g., "transients"), yet these understandings and terminologies reveal themselves to be nuanced, and even contradictory.

For instance, during a set of questions about what constitute the most pressing problems in the downtown area, we identified divisions and commonalities both between and within each group. Aspects of drug use were raised as problems in all four interviews. Some seniors tend to understand drug use as holistically tied to vagrancy, violence, and "panhandling."

Jack: I guess it gets a little rough downtown, and when they get drinking and get some drugs inside of them they get pretty brave.

Chester: Now you've got the downtown area that's integrated into the drugs, the homeless and the transients. You've got four different societies you might call them. In one. They've actually joined to become one. (...) The panhandlers are getting too aggressive ... they're getting very, very aggressive, and that's the people you've got to worry about.

Muriel: And there was another incident about this summer, where a man, two boys came up to a man, asked him the time, and when he bent down to look at his watch they slit him open!

Shelter clients offer more nuanced definitions of what they consider to be drug-related problems. They acknowledge extensive drug use within street populations, but perceive social problems more acutely in other types of activity.

Anthony: ... speaking from experience, I've lived here four years and I feel a lot safer here than with those guys who come out of the bars. I find them more dangerous than the guys I live with.

Seniors and shelter clients also join in blaming "transients" for violence and other downtown problems. The use of this term, and the general idea that Kelowna's problems are attributable to outsiders, is prevalent in media and political narratives as well as official policy discourse in the 
city. Some shelter clients ascribe violence and breaches of drug-taking etiquette to people who are new or unattached to Kelowna, whether tourists, seasonal workers, or drifters.

Joe: A lot of people come here on holidays. They're here for a couple of days, couple of weeks, and they don't care what they do to this town, they don't care who they hurt in this town. Who cares if I get into a fight, kick this, smash this ... who gives a shit?"

Peter: I clean myself up and shit, but it's those people who come in from other cities and shit, who've got no respect for nothing, that's the people you gotta worry about.

Of the fifteen shelter clients who participated in our interview groups, six claim to have lived in Kelowna for less than a year and most are aware of their own proximity to the transient category by virtue of their dwelling places and daily activities. This forces clients to make distinctions between problematic transients and ordinary "street people."

Trevor: They all seem to come to town at the same time you know. They set themselves up on the highway; they all seem to hit the same Salvation Army on the same day. There are a lot of them around. If you go to the bus stop it looks like the beginning of a Lollapalooza Festival.

Terms such as transients, which are deployed in policy rhetoric may reveal themselves to be "floating signifiers" - seemingly coherent references to specific publics, yet of varied meaning (Levi-Strauss 1987).

The data presented thus far suggest that understandings of threats to safety and problematic populations/activity are not homogenous among the group participants. Seniors and shelter clients exhibit group-specific concerns, and they are attuned to the fact that certain issues are common to others of the same "type." We make no claims that seniors and clients are active "counterpublics" (Burawoy 2005), but in the narrow context of our opening interview topics, each public exhibits a considerable degree of thickness. They recognize themselves as belonging to distinct (visible) groups who face common issues, and they employ common codes to understand these issues (coherence).

\section{Awareness of CCTV}

Having assessed the initial "thickness" of each public, we then examined awareness of the cameras. Our original intention was to assess the degree to which Kelowna authorities had met the OPC's recommendations regarding publicization of monitoring practices. ${ }^{10}$ These data also provide

10. OPC (2006) guideline number seven reads, "The public should be advised that they will be under surveillance." 
insights into the resources that publics draw on to make sense of certain issues in the absence of direct consultation/address. Our research reveals that, regardless of population type, awareness about Kelowna's monitoring program is generally low and/or inaccurate. Almost every participant knows there are cameras in Kelowna, but few participants are sure where the cameras are located. Only two seniors - one of whom is a retired RCMP officer - are aware of the two locations where cameras are installed. Shelter clients are equally unsure as to the scope of the surveillance cameras. Nor are they able to distinguish between on-street monitoring and video surveillance systems that operate in stores, banks, and parking lots. Even after we explicitly identify which cameras our study is concerned with, clients at the Gospel Mission continue to conflate the traffic monitoring cameras with the streetscape system. Both populations speculate inaccurately about the location and scope of the program.

Trevor: There's a ton of them up and down this street ... those cameras can zoom in on your shoelaces.

Chester (senior): The transients and the drug problem. It's in the park. So, surveillance ... I think they're stepping up the surveillance in the last year, and I believe it's getting better.

Awareness of how the monitoring scheme is conducted is equally low across both publics.

Issues of uncertainty include who is responsible for monitoring, whether the cameras are recorded, and when the cameras are operational. One explanation for the low levels of knowledge about the scheme is the range of resources that participants draw on to infer about video surveillance in Kelowna. Most participants indicate that they learn about camera surveillance from newspapers and other media.

Anthony (shelter client): I'm speculating that they're moving these cameras, like moving on a chessboard (...) One time I saw, there's a woman there, they showed it on the news one time, just one woman there who's got a wall of cameras.

Muriel (senior): Well, yes I read about it. I knew they were there but only when they came to be there, it was in the paper or something.

None of the participants have ever been involved in - or are even aware of - public consultation of any kind; not one of the participants remembers having their opinion solicited in any form before or since the establishment of the program.

R: Did anyone ever ask your opinion about this? Was there a chance to go to city hall and give your say? 
Trevor: No, there was no plebiscite! [laughter]

R: What about a leaflet?

[prolonged laughter]

Derek: Nothing, it was just up!

These findings speak to Kelowna's failure to meet the OPC expectations, but reveal little about the distinctiveness of either public in terms of level of awareness. It is unclear whether either public became more or less aware of the cameras as a result of their respective group situation, although, by the end of the interviews, participants were made aware of the locations and protocols of the cameras in Kelowna by the interviewer.

\section{Opinions about CCTV, Crime, and Safety}

Opinions are crucial to the public sociologist, insofar as the goal is to create a dialogue between publics and scholars on various issues. Gauging opinions aids the organic public sociologist in articulating scientific objectives for issues of importance to thick publics. Integrated opinions can also help to identify a thick public to work with in the first place. During our interviews, we elicited opinions about CCTV cameras in order to explore whether official claims made on behalf of seniors, and about street populations, were reflected in the opinions of the respective "real" populations. One hypothesis derived from the official claims would predict seniors to approve of cameras, and shelter clients to express more reservations or apathy. Our original aims were to test the assumptions of official discourse, but our method entailed determining whether the issue of video surveillance constitutes two distinct publics with different but internally integrated normative stances vis-à-vis the cameras.

Our participants tend to support the cameras, almost unanimously in the case of seniors, and in approximately half of all cases of shelter clients. We cannot be more specific, as several participants changed their minds during the interviews. Reasons for supporting cameras mirror many of those found in official discourse. Two assumptions prevail, the first of which is that video surveillance effectively deters crime.

Chester (senior): Surveillance helps, let's put it that way, it is a deterrent and it certainly helps. I don't care what areas they are in: it helps.

Muriel (senior): It depends though, if it could be seen, if they could be recognized, I think that would be a deterrent. If someone could see that it was you there ... anonymity is a great protection.

Bob (shelter client): In Sydney Australia, or actually it was in England, the crime rate dropped $50 \%$ after they put the cameras in. 
A second recurring opinion is that public monitoring can aid in responses to crime and after-the-fact investigations. Like seniors, shelter clients assume cameras are useful for crime detection - although we encountered more skepticism in this group. One shelter client suggests the cameras may help to catch "crack-heads," or other drug users who are less careful than he (the individual admitted to a drug habit). Another believes cameras might capture crimes in progress, although his statement echoes his peers' skepticism that criminals are likely to blunder in this way.

Trevor: By fluke they might catch a burglary.

Because concerns about public safety feature prominently in video surveillance rhetoric, ${ }^{11}$ we asked both populations for opinions on whether the cameras addressed their own safety concerns. Participants are aware that cameras are intended to aid in the perception of safety in the downtown. As one shelter client remarks: "The majority of these cameras are in place ... to make sure the public feel a lot safer in the streets" (Adrian). However, when asked if the cameras make participants feel any safer, seniors' responses are largely indifferent or negative.

R: Do you think things are any safer with them being there?

Muriel: The one on Leon. And at Queensway I think has made a difference.

Maude: I don't know if we're any safer.

R: So when politicians say we need to have surveillance cameras because, for one reason, cameras make seniors feels safer, are they telling the truth?

Muriel: No, I don't think about it.

Edith: No.

Shelter clients are also dubious about the safety benefits of cameras. When questioned on the ability of the cameras to make other citizens feel safer downtown, one shelter client opines:

Douglas: I wouldn't bring my daughter down here. When I see the camera I don't think "yeah I'll bring my whole family down here" because it

11. In a CCTV promotional press release provided to CTV National News on Tuesday October 2, 2001, Kelowna officials cite municipal survey results to claim "public safety is a top priority of Kelowna residents." The Community Indicators Report No. 1 (City of Kelowna, 1999:16) reports "In particular, the older population is considered to be high maintenance by the police, due to their perceptions and fears of crime," and comments on the fact that high concentration of seniors live in the downtown area. 
would be six months later until they found the guy who murdered everyone, my kids would be toast!

Although neither groups' safety concerns are significantly alleviated by knowing that there are cameras in Kelowna - the most notable departure from official discourse - each public rationalizes their opinions in somewhat distinct ways. Seniors may ostensibly approve of cameras, but do not believe they can expedite interventions in immediate crises of safety. Shelter clients, for the most part, consider their safety concerns (police violence, dangerous traffic) to be fundamentally disconnected from any utility cameras might have. Shelter clients complain that cameras aid the police in harassing and dispersing groups of street dwellers, and some object to the unavoidable invasions of privacy stemming from the positioning of the cameras outside their support services. It is not unreasonable to conclude that some shelter clients actually find video surveillance detrimental to their safety in some ways. But they also find reasons to approve of cameras in terms of policing reckless and dangerous others. Consistent with Huey's (2010) research, we were unable to find a significantly integrated normative stance toward camera surveillance among street-involved people. Collectively, our participants' opinions are somewhat supportive of authorities' arguments for cameras as a crime detection tool, but wholly unsupportive of the idea that cameras enhance safety.

\section{Rationality, Resources, and Opinion}

The final component of the focused-group interviews entails an exploration of the resources and rationales that participants draw upon in expressing their opinions about cameras. Since the lack of public consultation is what prompted us to conduct this research, we wanted to explore two critical issues: the resources used to evaluate public cameras in the absence of consultation; and whether sociological research may be influential in shaping public opinion. The first issue is addressed by analyzing how participants make their points regarding opinions. To address the second issue, we introduced sociological findings during the course of the interviews to see if participants were persuaded or interested by it. In the context of public sociology, the principle of instrumental rationalization indicates a relationship whereby sociological expertise and public interests find a common ground in praxis. While we do not claim to have significantly tested this idea by mentioning research conclusions during our interviews, our findings do suggest that publics - whether thick or thin - may find other communicative logics more accessible and appealing. 
Both publics draw on a diverse range of resources to understand and evaluate cameras. Participants base many of their assumptions on media representations and references to the successful uses of video surveillance in other contexts (e.g., in Britain or in relation to terrorism).

Joe (shelter client): In England if there's a criminal that does something, they can follow that person for miles and miles, automatically.

Jane (senior): Well, I was very impressed with the way the cameras had worked after that last bombing [July 7, 2005 terrorist bombing in London, $\mathrm{UK}]$ on the subway and the bus....

While practically every participant can recall outside, mediated examples of the success of cameras, not one participant can provide a local example of successful video surveillance use. ${ }^{12}$ The lack of local evidence about CCTV efficacy, even when we identified it during the interviews, has no effect on generally positive approval levels. It also does not seem to matter that participants had earlier disputed the ability of cameras to protect their safety. Secondary anecdotes and stories about the cameras satisfy participants that the cameras must be doing something positive - and are therefore worth keeping.

To challenge what appeared to be fairly dogmatic support for the cameras, we introduced findings of sociological research during the interviews. In particular, we used material that posed challenges to participants' beliefs about CCTV, to assess the persuasiveness and accessibility of social-scientific arguments. We found that participants sometimes reflect upon or modify given reasons for certain beliefs about CCTV when presented with contrary research evidence. However, other forms of nonscientific knowledge are far more influential in securing positive opinions about CCTV.

During discussions about the deterrent effect of cameras, we referred to research suggesting that street lighting might be as, or more, effective as a deterrent (Painter and Tilley 1999). One senior's response marks a modification of her earlier stance concerning CCTV as a deterrent.

Muriel: I don't think it stops crime, I think it stirs them up and prevents accumulation of crimes in certain areas that are detrimental to the city's growth and safety.

When the deterrent effect of the cameras is similarly questioned with the other group of seniors, several reflect upon and revise prior assumptions.

12. At the time of these interviews, Kelowna's CCTV program had been operating for around five years. 
R: If I were a drug dealer, I'd just go the next street. What kind of deterrent is that?

Frances: True.

Brenda: That's true.

( ...)

Chester: I don't know about the overall picture, depending on where the area is. A drug area like we have over on Leon Avenue, there was a camera there monitored 24 hours a day. You might not have that problem, but it would go somewhere else.

Most positive opinions about cameras derive less from specific rationales about deterrence and detection, and more from widely held beliefs that cameras will somehow counter abhorrent types of crime (also see Scanlon 2008). During the interviews, participants from both publics express outrage and alarm about stabbings, attacks on the vulnerable (the elderly and children), and other unambiguously negative and violent actions. As one shelter client summarizes, "It's an alright system if it's used for protecting against violence." We raised the subject of Jamie Bulger, a British toddler who was abducted and later killed by two young boys (Hay 1995). Footage from a shopping mall security camera that shows the child being led away from his mother, ultimately to his death, are perhaps the most emblematic imagery captured on video surveillance. All of the participants were familiar with the case. We broached the topic to present the argument that video surveillance was unable to prevent the murder, expecting participants to reflect on their support for cameras in "protecting against violence." Our efforts had the opposite effect. Simply articulating an abhorrent crime with a symbolic tool of crime control (video surveillance) produces renewed approval of monitoring schemes. Any rationale concerning the futility of cameras is eclipsed by a shared moral outrage at the gravity of the crime. Only one shelter client attempts to vocalize the shortcomings of the cameras in this respect:

Joe: Who was watching while those kids walked him away? Those cameras did absolutely nothing. All that camera did was allow us to go back and watch it, how did it help that kid?

Mark: It brings peace of mind, at least you know what happened.

However, following a sustained discussion about shocking instances of "beatings" and "stompings," the same individual (who had himself claimed to have been beaten-up by police) altered his opinion:

Joe: Well, at the outset I was totally against the cameras, but after hearing the guys talking about safety, kids and ... well, I'm more toward that. 
Scholars have established the role of "signal crimes" and other stylized events with emotive impact in generating support for public policies including video surveillance that may otherwise have failed to materialize (Hier et al. 2007; Innes 2004; Hay 1995). The political potency of signal crimes points to the impotence of long-term evidentiary modes of reasoning compared with more immediate, emotionally involving rationalities. Our attempts to argue that the reductive effect of video surveillance on violent crimes is empirically unsubstantiated (see Welsh and Farrington, 2009; Gill and Spriggs 2005; Painter and Tilley 1999) fell on deaf ears. Noting that sociological evidence shows that public CCTV monitoring is mostly useful in preventing localized vandalism and theft of/from vehicles in parking lots (Gill and Spriggs 2005; Tilley 1993) and property crime (Armitage 2002; Armitage et al. 1999; Squires 1998) also failed to impress our participants. In other words, the issue of safety is one where evidence-based sociological arguments about video surveillance are not an effective platform for communication, because, as Mesny (2009) notes, some publics feel more comfortable with different forms of knowledge, especially concerning particular issues such as harm, safety, and security.

\section{Conclusion}

The success of traditional and organic public sociology depends on three achievements: to conform to the communicative logics of intended audiences; to align research objectives with the inchoate and integrated interests of, respectively, thin and thick publics; and to produce scientifically robust work capable of influencing popular struggles. Our investigation illustrates challenges to public sociology on all three levels. Neither traditional nor organic approaches have had much success in influencing video surveillance policy making, or in stimulating a broad and critical civic conversation on the subject.

Two factors contribute to the lack of influence. First, identifying and engaging thick and thin publics who are receptive to the ways that sociologists frame research problems can be challenging. Second, the concept of reflexive instrumentalism is undermined by the multiplicity of rationalities at work in the agendas of real-life publics (also see Butler 2009; Goldberg and van den Berg 2009; Acker 2005; Ryan 2005; Brady 2004).

Our interviews suggest that seniors and shelter clients in Kelowna constitute groups whose interests are somewhat aligned in respect of their life situations. However, thick publics are not absolute: they exist 
only insofar as their integration produces consistent agendas in relation to issues at hand. For example, antipoverty activist groups may be thick in relation to questions of social housing and welfare, yet less integrated on the issue of pollution. Our interviews in Kelowna were structured around the issue of video surveillance cameras because of the focus of our broader research agenda. Therefore, our research does not conform strictly to Burawoy's project of organic public sociology; it was not developed in cooperation with our participants. Given the low levels of awareness and prior concern about cameras, it is unlikely that an organic attempt to work with seniors or shelter clients on matters of concern in the downtown would lead to an inquiry about cameras. Likewise, it is unsurprising that we did not encounter integrated critical stances about the cameras (particularly among the shelter clients) because our research problem was based on theoretical (prevalence of cameras versus lack of evidence of effectiveness), normative (democratic principle of public inclusion in policy), and political (ineffectiveness of the OPC guidelines) knowledge that does not always correspond to lay problem frames.

One might conclude that scholastic concerns about cameras - deriving from theoretical and empirical critical thought about surveillance - are better served via traditional public sociology, given the thin nature of publics involved. A problem with this conclusion is that there is already an abundance of critical sociology published on this subject (see Hier 2010; Huey 2010; Welsh and Farrington 2009 for an overview). We have participated in conferences about surveillance in Canada and abroad, published our own findings in journal articles and books, and participated in multiple media forums dedicated to video surveillance. Yet our research reveals that very little of this work surfaces in public debates or policymaking efforts pertaining to camera surveillance. Even counterpublics, thick or thin, are far more likely to use "Big Brother" as the foundation for arguments against public cameras, than to refer to scholarly literature.

Of course, traditional and organic public sociology are not mutually exclusive. Burawoy (2005a) recognizes that public sociology requires creative thinking to bring research to bear in real situations. Our most successful attempts to embed research in civic discourse have been through direct contact with thicker, usually institutionalized, publics such as politicians and other public servants. Even in these cases, thick publics will only enter into organic relationships with sociologists if they are (1) receptive to social-scientific knowledge, and (2) in immediate need of the kind of research we have to offer. In some cases the sociologist may achieve a satisfactorily mutual relationship with a public - furthering his/her understanding of their needs, and contributing to 
their decision-making process. In other cases, there is an uneasy feeling that the sociologist's work is merely a means to legitimize preconceived policies. Unfortunately, due to the nature of our research (and those of many other sociologists), we often only become aware of objects of interest (camera programs) when they are already established or at an advanced stage of planning the system. Organic interactions at this stage are unlikely to be influential, particularly if there is no identifiably thick counterpublic to approach.

The prospects for instrumental rationality, therefore, are far from clear. Both traditional and organic public sociologies can make research available, but the dominant rationalities and agendas of the publics involved tend to dictate the terms of engagement. Simply put, the promotion of rational discourse involving social-scientific, or other pieces of rational academic research - or "facts and figures" - does not resonate with some publics (Mesny 2009). Compromises involved in adapting to public needs and communication logics may erode the reciprocal dynamics a civic conversation demands. Orienting research entirely to the preconceived needs of publics transforms attempts at public sociology into policy sociology "in the service of a goal defined by a client" (Burawoy 2005:266). Our attempt to open a dialogue about cameras has to do with our desire to bring our sociological research and observations, as one "bundle" (Kalleberg 2005) of knowledge, into a conversation with others. In the field, however, public sociology is easier said than done.

\section{REFERENCES}

Acker, J. 2005. Comments on Burawoy on public sociology. Critical Sociology 31(3):328-331.

Armitage, R. 2002. To CCTV or not to CCTV? A Review of Current Research into the Effectiveness of CCTV Systems in Reducing Crime. London: Nacro.

Armitage, R., G. Smyth, and K. Pease. 1999. Burnley CCTV evaluation. In K. Painter and N. Tilley, eds., Surveillance of Public Space: CCTV, Street Lighting and Crime Prevention. Crime Prevention Series Volume 10. Mounsey: Criminal Justice Press.

Beck, U. 2005. How not to become a museum piece. British Journal of Sociology 56(3):335-343.

Bennett, C. and R. Bayley. 2005. Video surveillance and privacy protection law in Canada. In S. Nouwt, B.R. de Vries, and C. Prins, eds., Reasonable Expectations of Privacy: Eleven Country Reports on Camera Surveillance and Workplace Privacy. The Hague: Asser Press.

Best, J. 2004. Threatened Children: Rhetoric and Concern about Child Victims. Chicago: University of Chicago Press. 
Brady, D. 2004. Why public sociology may fail. Social Forces 82(4):1629-1638.

Burawoy, M. 2009. Disciplinary mosaic: The case of Canadian sociology. Canadian Journal of Sociology 34(3):869-886.

2005a. 2004 American Sociological Association Presidential Address: For public sociology. British Journal of Sociology 56(2):259-294.

2005b. Response: Public sociology: Populist fad or path to renewal? British Journal of Sociology 56(3):417-432.

2005c. The critical turn to public sociology. Critical Sociology 31(3):313-326.

2005d. Rejoinder: Toward a critical public sociology. Critical Sociology 31(3):379-390.

2004. Public sociologies: Contradictions, dilemmas and possibilities. Social Forces 82(4):1603-18.

2003. For a sociological Marxism: The complementary convergence of Antonio Gramsci and Karl Polanyi. Politics and Society 31(2):193-261.

Burawoy, M., W. Gamson, C. Ryan, S. Pfohl, D. Vaughan, C. Derber, and J. Schor. 2004. Public sociologies: A symposium from Boston College. Social Problems 51(1):103-130.

Butler, K. 2009. Blurring public and private sociology: Challenging an artificial division. Sociological Research Online, 14, no. 4. http://www.socresonline.org.uk/14/4/2.html (accessed April 10, 2010).

Calhoun, C. 2005. The promise of public sociology. British Journal of Criminology 56(3):355-363.

City of Kelowna. 1999. Community Indicators Report No. 1: A Benchmark for Kelowna, British Columbia. Kelowna, BC: Department of Planning and Development Services.

Davis, P. 2004. Sociology and policy science: Just in time? British Journal of Sociology 55(3):447-450.

Dovey, K., J. Fitzgerald, and Y. Choi. 2001. Safety becomes danger: Dilemmas of drug-use in public space. Health and Place 7:319-331.

Ericson, R. 2005. Publicizing sociology. British Journal of Sociology 56(3):365372.

Gill, M. and A. Spriggs. 2005. Assessing the Impact of CCTV. Home Office Research Study 292. London: Home Office.

Gill, M. 2003. CCTV. Leicester: Perpetuity.

Glenn, E. 2007. Whose public sociology? The subaltern speaks but who is listening? In D. Clawson, D. and R. Zussman, eds., Public Sociology: Fifteen Eminent Sociologists Debate Politics and the Profession in the TwentyFirst Century. Berkeley: University of California Press.

Goldberg, A. and A. van den Berg. 2009. What do public sociologists do? A critique of Burawoy. Canadian Journal of Sociology 34(4):765-795. 
Grim, J., A. Harmon, and J. Gromis. 2006. Focused group interviews as an innovative Quanti-Qualitative Methodology (QQM): Integrating quantitative elements into a qualitative methodology. The Qualitative Report 3:516-537.

Haggerty, K. 2004. Displaced expertise: Three constraints on the policy relevance of criminological thought. Theoretical Criminology 8(2):211-231.

Hay, C. 1995. Mobilization through interpellation: James Bulger, juvenile crime and the construction of a moral panic. Social and Legal Studies 4(2):197223.

Hier, S. 2010. Panoptic Dreams: Streetscape Video Surveillance in Canada. Vancouver: UBC Press.

Hier, S., J. Greenberg, K. Walby, and D. Lett. 2007. Media, communication and the establishment of public camera surveillance programs in Canada. Media, Culture and Society 29(5):721-751.

Hier, S., K. Walby, and J. Greenberg. 2006. Supplementing the panoptic paradigm: Surveillance, moral governance, and CCTV. Pp. 230-244 in D. Lyon, ed., Theorizing Surveillance: The Panopticon and Beyond. Cullompton: Willan.

Huey, L. 2010. False security or greater social inclusion? Exploring perceptions of CCTV use in public and private spaces accessed by the homeless. British Journal of Sociology 61(1):63-82.

Innes, M. 2004. Signal crimes and signal disorders: Notes on deviance as communicative action. British Journal of Sociology 55(3):335-355.

Johnson, P. 2004. Making social science useful. British Journal of Sociology 55(1):23-30.

Kalleberg, R. 2005. What is 'public sociology'? Why and how should it be made stronger? British Journal of Sociology 56(3):387-393.

Lett, D. 2007. Bringing into focus the experience of public camera surveillance. MA thesis, University of Victoria.

Levi-Strauss, C. 1987. Introduction to Marcel Mauss. London: Routledge.

Matthews, R. 2009. Beyond 'so what?' criminology: Rediscovering realism. Theoretical Criminology 13(3):341-362.

Mesny, A. 2009. What do 'we' know that 'they' don't? Sociologists' versus nonsociologists' knowledge. Canadian Journal of Sociology 34(3):671-695.

Morgan, D. 1997. Focus Groups as Qualitative Research. Second edition. Thousand Oaks, CA: Sage.

Norris, C., M. McCahill, and D. Wood. 2004. The growth of CCTV: A global perspective on the international diffusion of video surveillance in publicly accessible space. Surveillance \& Society 2(2/3):110-135.

Office of the Privacy Commissioner of Canada (OPC). 2006. OPC guidelines for the use of video surveillance of public places by police and law enforce- 
ment authorities. http://www.priv.gc.ca/information/guide/vs 060301 e. cfm (accessed December 10, 2009).

Painter, K. and N. Tilley. 1999. Surveillance of Public Space: CCTV, Street Lighting and Crime Reduction. Crime Prevention Series Volume 10. Mounsey: Criminal Justice Press.

Piven, F. 2007. From public sociology to politicized sociologist. In D. Clawson, and R. Zussman, eds., Public Sociology: Fifteen Eminent Sociologists Debate Politics and the Profession in the Twenty-First Century. Berkeley: University of California Press.

Ryan, C. 2005. Can we Be Campañeros? Social Problems 51(1):110-113.

Said, E. 1994. Representations of the Intellectual. New York: Vintage Books.

Scanlon, J. 2008. CCTV in the United Kingdom: Britons apparently like Big Brother watching them. Pp. 170-176 in J. Greenberg and C. Elliott, eds., Communication in Question: Competing Perspectives on Controversial Issues in Communication Studies. Toronto: Thomson-Nelson.

Squires, P. 1998. An Evaluation of Ilford Town Centre CCTV Scheme. Brighton: Health and Social Policy Research Centre, University of Brighton.

Tilley, N. 1993. Understanding Car-parks, Crime and CCTV: Evaluation Lessons from Safer Cities. Crime Prevention Unit Paper 42. London: Home Office.

Waples, S. and M. Gill. 2006. Effectiveness of redeployable CCTV. Crime Prevention and Community Safety 8(1):1-16.

Wiles, P. 2004. Policy and sociology. British Journal of Sociology 55(1):31-34.

Welsh, B. and D. Farrington. 2009. Making Public Places Safer: Surveillance and Crimes Prevention. Oxford: Oxford University Press.

2004. Evidence-based crime prevention: The effectiveness of CCTV. Crime Prevention and Community Safety 6(2):21-33.

Dan Lett is a PhD Candidate at the Department of Sociology, University of Victoria. He has published peer-review articles on video surveillance (2007, Media, Culture and Society, with S. Hier, J. Greenberg and K. Walby), and an edited volume on racism titled Racism and Justice (2009, with S. Hier and S Bolaria). Dan studies the establishment and administration of streetscape video surveillance projects in Canada. His other interests include science and metaphysics, and craft industries.

dplett@uvic.ca

Sean Hier is associate professor of sociology, University of Victoria. His recent book is Panoptic Dreams: Streetscape Video Surveillance in Canada (UBC Press)

shier@uvic.ca

Kevin Walby is a SSHRC Postdoctoral Fellow at the Centre of Criminology, University of Toronto. He has a $\mathrm{PhD}$ in sociology from Carleton University. Peer reviewed articles include Qualitative Research (2010), International Soci- 
ology (2011, with S. Hier), Social Movement Studies (2011, with J. Monaghan), the British Journal of Criminology (2010, with J. Piché), Punishment \& Society (2011, with J. Piché), Criminology and Criminal Justice (2010, with N. Carrier), and Social \& Legal Studies (2007). Walby is working on an edited volume entitled Brokering Access: Power, Politics and Freedom of Information Process in Canada with Mike Larsen, an edited volume entitled Emotions Matter with Alan Hunt and Dale Spencer, and a book entitled Touching Encounters: Sex, Work, and Male-for-Male Internet Escorting. He is the prisoners' struggles editor for the Journal of Prisoners on Prisons. 